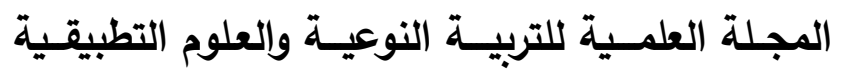

The Scientific Journal of Specific Education and Applied Sciences

\title{
Potential Effects of cooking conditions and substitution with carrot and pumpkin on quality attributes of orange sweet potato jam
}

\author{
Hanan El-Sayed \\ Food Science Department (rural Home Economics), Fac. Agric., Zagazig \\ Univ., Egypt.
}

Taha F. Taha

Department of Biochemistry, Fac.Agric, Zagazig Univ., Egypt.

\section{Eman T. Abou Sayed Ahmed}

Food Science Department, Fac.Agric, Zagazig Univ., Egypt.

\begin{abstract}
The current study designed to explain the appropriate cooking method of sweet potato and evaluate the effect of various substitution ratios with carrot and pumpkin on the quality attributes of sweet potato jam (sensory characteristics, chemical composition, total phenolic and flavonoid components, antioxidant activity, and color). The heat pretreatments included microwave heating, grilling, traditional boiling, and under pressure boiling. The Jam was prepared from under pressure pretreated sweet potatoes (control) and from different supplementation from pumpkin and carrot. The results showed that under pressure boiling was the best heat pretreatment for sweet potato maintaining the maximum levels of total phenolic and flavonoid components and antioxidant activity. Also, the results indicated that there was a slight decrease was observed, due to heat processing, of total polyphenol contents and antioxidant activity of sweet potato, which was ranged from $0.51 \pm 0.1$ to $0.78 \pm 0.1 \mathrm{~g} / \mathrm{g}$ dried extract and $55.54 \pm 0.3$ to $68.22 \pm 0.5 \%$ respectively. In this respect, pressure boiling was exhibited the lowest decrease among the four processing methods (microwaving, boiling, grilling and pressure boiling). The results indicated that potato jam blended with carrot and pumpkin had the highest total polyphenol contents and
\end{abstract}




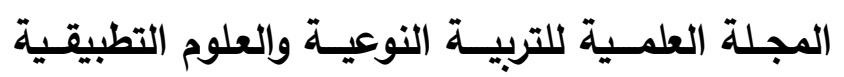

The Scientific Journal of Specific Education and Applied Sciences

antioxidant activity $0.77 \pm 0.0 \mathrm{~g} / \mathrm{g}$ dried extract and $65.41 \pm 0.4 \%$ respectively. The overall acceptability of the jam is good.

Key words: Cooking, Total phenolic content, Flavonoids, Antioxidant activity, color.

\section{Introduction}

Sweet potato (Ipomoea batatas L) is a starchy tuberous root vegetable that into the family of Convolvulaceae (Devi et al., 2018) and is cultured in tropic and hot temperatures belong in the whole world for its nutritious and health-promoting value. Sweet potato is known in Egypt as batata.

Oke and Workneh, (2013) reported that sweet potato is an important root crop grown all over the world and can be eating as a vegetable, boiled, baked, or often fermented into diet and drinks. It could be a very good source to some health-related problems and help as nutrition safety.

Sweet potato crops are among the world's most important. It could be using as a subsistence, food safety, its uses have expanded considerably in the developing countries as observed by (Sathe and Salunkhe, 1999).

Evaluated sweet potato protein $(0.46 \%$ to $2.93 \%)$, dietary fiber ( $0.49 \%$ to $4.71 \%)$, lipid ( $0.06 \%$ to $0.48 \%)$ and ash $(0.31 \%$ to $1.06 \%$ ). It contains essential mineral nutrients such as $\mathrm{Ca}, \mathrm{P}, \mathrm{Mg}, \mathrm{Na}$, $\mathrm{K}, \mathrm{S}, \mathrm{Fe}, \mathrm{Cu}, \mathrm{Zn}, \mathrm{Mn}, \mathrm{Al}$, and $\mathrm{B}$. Sweet potato have an important source of vitamin A, thiamin, riboflavin, niacin, ascorbic acid, and many other functional foods (Woolfe, 1992).

Compared to other vegetables considered sweet potato as super-food because of its multipurpose and enjoyable taste and high nutritional value. Today, sweet potato has complex medicinal properties such as anti-cancer, anti-diabetic, anti-oxidant, antibacterial, anti-inflammatory, anti-fungal, anti-viral, anti-ulcer, hepatoprotective and defend cigarette smokers from emphysema. Sweet potatoes contents are high potassium and contain magnesium a crucial mineral that can alleviate muscle cramps and mood nerve health (Milind and Monika, 2015). 


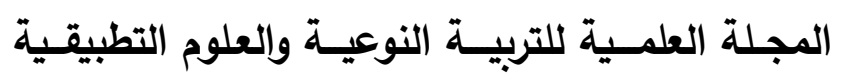

The Scientific Journal of Specific Education and Applied Sciences

Sweet potatoes are good sources of vitamins $\mathrm{C}$ and $\mathrm{E}$ as well as dietary fiber, potassium, and iron, polyphenols, and carotenoids. They are low in fat and cholesterol. It considered an important protein source for several world peoples and is an important source of starch and other carbohydrates which are considered useful health nutrients, where these were evaluated before by (Benjamin, 2007 and Padmaja, 2009). On the other hand Abubakar, et al., 2010 revealed that sweet potatoes can be used to reduce malnutrition in society consequently increased production.

The sweet potato varieties in Rwanda was the moisture content quite high and ranged between $62.58 \pm 0.42$ to $64.34 \pm 0.42$. The crude proteins $(0.91 \pm 0.05)$. Dietary fiber ranged from $0.11 \pm 0.00$ to $0.14 \pm 0.00$, while the concentration of minerals was quite less than $0.40 \pm 0.02$ to $0.44 \pm 0.07$, these results were investigated by (Rose and Vasanthakaalam, 2011).

Jam is a semi-solid nutrition product, contented upon cooking fruits or vegetable pulp with sugar, citric acid, and pectin. Jam can be defined as an middle moisture food produced by cooking sugar with fruit pulp, pectin, acid and other ingredients to a sensible constancy where described that in their study (Ullah et al., 2018).

The eating of carrots and carrot foods products grows gradually because the vegetable is thought to be vital source of natural antioxidants with anticancer activity, (Sharma et al., 2012) who revealed that in their study. Carrots are a virtuous source of carbohydrates, minerals such as $\mathrm{Ca}, \mathrm{Fe}, \mathrm{Na}, \mathrm{K}, \mathrm{Mg}, \mathrm{Cu}, \mathrm{Zn}$, carotenes, thiamine, riboflavin, niacin and vitamin $\mathrm{C}$ (Arscot and Tanumihardio 2010, and Sharma et al., 2012). Carrot is a important source of many vitamins like A, C, $\beta$-carotene, B1, B2 and B3 and minerals like calcium, potassium, phosphorus and sodium, also carrot is a rich source of dietary fibers, carotenoids and phenols compounds (Krinsky and Johmson 2005) \& (Bao and Chang 1994).

Mukesh et al., (2010) revealed that the Pumpkin is one of the defined comestible plants that has considerable medicinal properties. It contains numerous phyto-constituents such as the categories of alkaloids, flavonoids, and palmitic, oleic and linoleic acids. Many vital medicinal properties belonging anti-diabetic, antioxidant, anticarcinogenic, anti-inflammatory. 


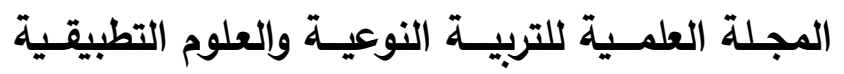

The Scientific Journal of Specific Education and Applied Sciences

Pumpkin belongs to the genus Cucurbita and the family Cucurbitaceae. Pumpkin fruit is one of the worlds known vegetables very rich in active antioxidants, and a valuable basis of carotenoids that was considered source of pro-vitamin A (Devi, et al., 2018). The $\beta$-carotene-rich foods in diets is the best measure to improve vitamin A nutrition of persons to overcome the problems and diseases caused by vitamin A deficiency (VAD) (Siems et al., 2005).

The current study aimed is to investigate the potential effect of the different methods of cooking conditions and substitution with carrot and pumpkin on the chemical composition, polyphenols and antioxidant activity and quality attributes of orange sweet potato jam.

\section{Materials}

\section{Raw materials}

Raw orange sweet potato tubers (Ipomoea batatas L), carrots (Daucu scarota L.), and pumpkin (Cucurbit apepo) were bought from the local market (Zagazig, Sharkia governorate, Egypt). All the vegetables were washed with clean tap water and the inedible parts were removed.

\section{Methods}

\section{Cooking of orange sweet potato}

The prepared orange sweet potato tubers were cut into parts with a size of $2 \mathrm{~cm}$ and divided into 5 groups which referred to as A, $\mathrm{B}, \mathrm{C}, \mathrm{D}$, and $\mathrm{E}$ in order to express the appropriate cooking method for jam manufacturing. Group A: control sample (fresh orange sweet potato sample without cooking), group B: traditionally blanched orange sweet potato sample in boiled water at $100^{\circ} \mathrm{C}$ for $15 \mathrm{~min}$, group C: under pressure cooked orange sweet potato sample; cooked for 9 min using a domestic pressure cooker, group D: microwaved orange sweet potato sample using a domestic microwave for $6 \mathrm{~min}$, and group E: grilled orange sweet potato sample using a domestic gas oven at $180^{\circ} \mathrm{C}$ for $30 \mathrm{~min}$.

\section{Jam preparation}

The jam was prepared from under pressure cooked orange sweet potato samples according to the obtained results. Only under 


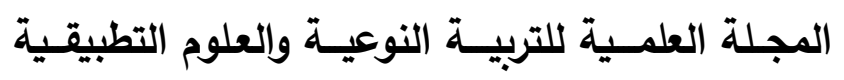

The Scientific Journal of Specific Education and Applied Sciences

pressure cooked orange sweet potato without substitution was used as a control sample for comparison. Three types of formulations were used for jam manufacturing through the substitution of under pressure cooked orange sweet potato samples with pumpkin, carrot, and a mixture of pumpkin and carrot; T1: pumpkin , T2: carrot, and T3: a mixture of pumpkin and carrot. The various substitution ratios were shown in Table (1). Citric acid and pectin were supplementary to each formulation and control by about $0.22 \mathrm{~g} / 100 \mathrm{~g}$ sample according to Desrosier and Desrosier (1977). While, sugar was added by about $60.8 \mathrm{~g} / 100 \mathrm{~g}$ sample. The cooking of jam was finished when the soluble solids reached to $67 \%$.

Table (1): Composition of different Jam formulations

\begin{tabular}{ccccccc}
\hline $\begin{array}{c}\text { Formul } \\
\text { ation }\end{array}$ & $\begin{array}{c}\text { Cooked sweet } \\
\text { potatoes under } \\
\text { pressure }(\mathbf{g})\end{array}$ & $\begin{array}{c}\text { Carrot } \\
(\mathbf{g})\end{array}$ & $\begin{array}{c}\text { Pumpkin } \\
(\mathbf{g})\end{array}$ & $\begin{array}{c}\text { Sugar } \\
(\mathbf{g})\end{array}$ & $\begin{array}{c}\text { Citric } \\
\text { acid } \\
(\mathbf{g})\end{array}$ & $\begin{array}{c}\text { Pect } \\
- \text {-in } \\
(\mathbf{g})\end{array}$ \\
\hline Con. & 450 & - & - & 550 & 1 & 1 \\
T1 & 225 & - & 225 & 550 & 1 & 1 \\
T2 & 225 & 225 & - & 550 & 1 & 1 \\
T3 & 150 & 150 & 150 & 550 & 1 & 1 \\
\hline
\end{tabular}

Con.: under pressure cooked orange sweet potato; T1: substitution of under pressure cooked orange sweet potato with pumpkin; T2: substitution of under pressure cooked orange sweet potato with carrot; T3: substitution of under pressure cooked orange sweet potato with mixture of pumpkin and carrot.

\section{Sensory Evaluation}

Both cooked orange sweet potato samples and various jams; control and different formulations, were sensorial evaluated. The different samples were presented to the panelists counting 25 members in coded samples with an instructed sheet. Moreover, the panelists were provided with a glass of water to rinse between each sample during the evaluation as described by Mounir et al., (2019). The panelists were asked to evaluate the different samples for their overall acceptability based on 1/appearance, 2/color, 3/taste, and 4/odor using a nine-point hedonic scale $(1=$ extremely dislike to $9=$ extremely like). (Leite et al., 2013). 


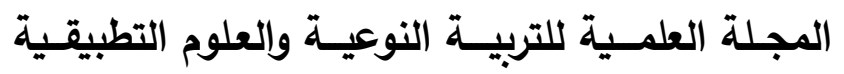

The Scientific Journal of Specific Education and Applied Sciences

\section{Proximate Chemical Composition}

The chemical composition of cooked sweet potatoes and various jams; control and different formulations, was determined. Moisture, fat, crude protein, ash and crude fiber contents, were evaluated by AOAC (2005). While, total carbohydrates were calculated by difference according to Guzman et al. (1999) using Eq. (1):Total carbohydrates $=$ Total Solids $(\mathrm{TS})-$ Fat + Protein + Ash) (1)

Energy density (E/ $100 \mathrm{~g}$ of sample) of cooked orange sweet potato and various jams; control and different formulations were calculated according to Insel et al., (2002) using Eq. 2:

Energy density $(\mathrm{E})=4($ Protein $\%+$ Carbohydrates \%) + 9 (Fat \%)

Mineral content was determined by sample drying and incineration. The ash was subsequently dissolved with hydrochloric acid to extract $\mathrm{P}, \mathrm{Ca}, \mathrm{Mg}, \mathrm{K}$ and Fe according to Jackson (1973). Phosphorus was determined according to Tsai et al., (1975). Calcium, Iron and zinc were evaluated by atomic absorption spectrophotometer by the recommendation of AOAC (1990)

\section{Total phenolic and flavonoid content}

The four different cooked products of sweet potato (cooking microwaved, cooking pressure boiled, cooking grilled, cooking boiled beside raw Potato as control) and jam control, $\mathrm{T}_{1}, \mathrm{~T}_{2}, \mathrm{~T}_{3}$ extracts were set up as portrayed by Rababah et al., (2004) with some adjustment. Fresh sweet potatoes were freeze- drying and around 20 $\mathrm{g}$ of each sample was weighed out and extracted with $200 \mathrm{~mL}$ of ethanol $70 \%$ while about $50 \mathrm{~g}$ of each crisp jam was weighted out, and extracted with $500 \mathrm{~mL}$ of methanol $80 \%$ under blending for 12 hr. Each concentrate was sifted through utilizing Whatman No. 3 channel paper, and stop drying until the end up powdered, and permitted to set in obscurity until investigation.

Total phenolic (TPC) and total flavonoid (TFC) contents were determined according to the methods defined by $\mathbf{X u}$ and Chang (2007) and Quettier-Deleu et al., (2000) respectively. 


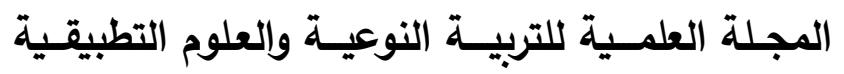

The Scientific Journal of Specific Education and Applied Sciences

\section{DPPH radical- scavenging activity}

The antioxidant activity was estimated by the DPPH $(2,2-$ diphenyl-1-picrylhydrazyl) assay according to Vijayakshmi and Kandasamy (2016). The changes in color (from deep violet to light yellow) were read at $517 \mathrm{~nm}$ after $100 \mathrm{~min}$ of reaction using a UVVIS spectrophotometer A mixture of ethanol $(3.3 \mathrm{ml})$ and the solution $(0.5 \mathrm{ml})$ was used as blank. The scavenging activity percentage (AOA \%) was calculated as follows:

$$
\operatorname{AOA}(\%)=\frac{A_{\text {blank }-A_{\text {sample }}}}{A_{\text {blank }}} \times 100
$$

DPPH free radical scavenging capacity was controlled by a colorimetric strategy with quercetin as an outer standard according to Vijayakshmi and Kandasamy (2016). The absorbance was estimated by the UV-Visible spectrophotometer at $517 \mathrm{~nm}$ against a negative control. DPPH searching rate $(\%)$ as $\mathrm{Y}$ estimation of the standard bend was determined by the condition $=[(\mathrm{A}$ blank $-\mathrm{A}$ sample)/Ablank] $\times 100 \%$.B.J.

\section{Color Characteristics}

The color parameters; $\mathrm{L}^{*}, \mathrm{a}^{*}$, and $\mathrm{b}^{*}$ of different samples was determined in triplicate presented by Mounir et al., (2019) using a Hunter's Lab color analyzer (Color Flex EZ Spectrophotometer, USA) that was calibrated with a black and white standard tile using the $L^{*} a^{*} b^{*}$ scale before measurement. Samples were placed in the standard cup and the color values of each sample were recorded and expressed as the mean of three replicated readings of $L^{*}(0$ : black, 100: white), $a^{*}$ ( $-a^{*}$ : greenness, $+a^{*}$ : redness), and $\mathrm{b}^{*}\left(-b^{*}\right.$ : blueness, $+b^{*}$ : yellowness).

\section{Statistical analysis}

The obtained results were exposed to examination of change (one- way ANOVA) using the SPSS program (version 16, 2007). Means were separated using Duncan's multiple range test at $p<0.05$ (Duncan, 1955). Results were offered as the mean \pm standard deviation (SD) of three triplicates 


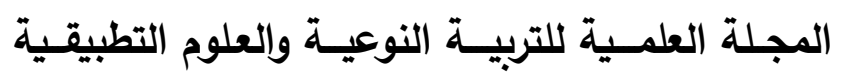

The Scientific Journal of Specific Education and Applied Sciences

\section{Results and Discussion}

\section{Sensory evaluation}

\section{Cooked orange sweet potato}

Table (2) demonstrations the sensory evaluation of different cooked orange sweet potato samples. Significant variations at $(p<$ $0.05)$ were showed in color and taste between the different cooked orange sweet potato samples. While, insignificant variations in odor, appearance, texture, and overall acceptability were observed at $p<$ 0.05 .

Results indicated that no clear difference in overall acceptability in grilled and Pressure boiled sweet potato whereas the lowest value was shown in cooking the microwaved sweet potato.

Table (2): sensorial characteristics of cooked orange sweet potato samples by different cooking methods.

\begin{tabular}{lcccccc}
\hline $\begin{array}{l}\text { Cooking } \\
\text { method }\end{array}$ & Color & Taste & Odor & Texture & Appearance & $\begin{array}{c}\text { Overall } \\
\text { Acceptability }\end{array}$ \\
\hline $\begin{array}{l}\text { Traditional hot } \\
\text { water boiling }\end{array}$ & $7.05 \pm 0.7^{\mathrm{b}}$ & $7.3 \pm 0.9^{\mathrm{b}}$ & $6.29 \pm 1.9^{\mathrm{a}}$ & $7.05 \pm 1.1^{\mathrm{a}}$ & $7.40 \pm 1.8^{\mathrm{a}}$ & $7.06 \pm 1.7^{\mathrm{a}}$ \\
$\begin{array}{l}\text { Microwave } \\
\begin{array}{l}\text { Under } \\
\text { Pressure } \\
\text { cooking }\end{array}\end{array}$ & $6.36 \pm 0.9^{\mathrm{c}}$ & $6.52 \pm 0.8^{\mathrm{c}}$ & $6.16 \pm 1.6^{\mathrm{b}}$ & $6.26 \pm 1.1^{\mathrm{b}}$ & $7.20 \pm 1.4^{\mathrm{a}}$ & $6.62 \pm 0.7^{\mathrm{b}}$ \\
Grilling & $7.92 \pm 0.9^{\mathrm{a}}$ & $8.00 \pm 0.9^{\mathrm{a}}$ & $7.83 \pm 1.3^{\mathrm{a}}$ & $7.96 \pm 0.7^{\mathrm{a}}$ & $7.93 \pm 0.9^{\mathrm{a}}$ & $7.65 \pm 0.0^{\mathrm{a}}$ \\
\hline
\end{tabular}

Mean values followed by different letters in the same column are significantly different at $\mathrm{P} \leq 0.05$.

\section{Orange sweet potato jam}

Formulated jams were sensory assessed for their color, taste, odor, texture, appearance and overall acceptability. The mean scores are presented in Table (3). It is obvious that no significant adverse effect on the color, taste, odor, texture, appearance and overall acceptability among $\mathrm{T} 1, \mathrm{~T} 2$ and $\mathrm{T} 3$. While, all sensory properties significantly decreased $(\mathrm{p} \leq 0.05)$ in control samples. In general, all samples scored well for all sensory parameters evaluated. These results agree with Nalinede et al., 2018, who prepared jam with different concentrations of sweet potato supplement with carrot and the overall acceptability of jam was good. 


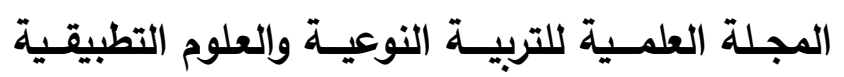

The Scientific Journal of Specific Education and Applied Sciences

Table (3): sensorial characteristics of different orange sweet potato jams; control and various formulations.

\begin{tabular}{lcccccc}
\hline Jam & Color & Taste & Odor & Texture & Appearance & $\begin{array}{c}\text { Overall } \\
\text { Acceptability }\end{array}$ \\
\hline Con. & $6.21 \pm 0.7^{\mathrm{b}}$ & $6.42 \pm 0.8^{\mathrm{b}}$ & $6.00 \pm 1.8^{\mathrm{b}}$ & $7.14 \pm 0.9^{\mathrm{b}}$ & $7.29 \pm 0.8^{\mathrm{b}}$ & $7.42 \pm 0.5^{\mathrm{b}}$ \\
T1 & $7.85 \pm 0.9^{\mathrm{a}}$ & $8.14 \pm 0.7^{\mathrm{a}}$ & $8.07 \pm 0.6^{\mathrm{a}}$ & $8.07 \pm 0.6^{\mathrm{a}}$ & $8.14 \pm 0.4^{\mathrm{a}}$ & $8.71 \pm 1.4^{\mathrm{a}}$ \\
T2 & $7.01 \pm 0.8^{\mathrm{a}}$ & $7.24 \pm 0.9^{\mathrm{a}}$ & $7.28 \pm 2.2^{\mathrm{a}}$ & $7.21 \pm 1.3^{\mathrm{a}}$ & $8.00 \pm 0.9^{\mathrm{a}}$ & $8.00 \pm 0.5^{\mathrm{a}}$ \\
T3 & $7.80 \pm 0.5^{\mathrm{a}}$ & $7.97 \pm 0.9^{\mathrm{a}}$ & $7.57 \pm 1.4^{\mathrm{a}}$ & $7.64 \pm 0.6^{\mathrm{a}}$ & $8.00 \pm 0.6^{\mathrm{a}}$ & $8.61 \pm 1.4^{\mathrm{a}}$ \\
\hline
\end{tabular}

Mean values followed by different letters in the same column are significantly different at $\mathrm{P} \leq 0.05$. T1: substitution of under pressure cooked orange sweet potato with pumpkin; T2: substitution of under pressure cooked orange sweet potato with carrot; T3: substitution of under pressure cooked orange sweet potato with mixture of pumpkin and carrot.

\section{Chemical composition}

\section{Cooked orange sweet potato}

The chemical composition of raw and processed potatoes is illustrated in Table (4). Boiling and pressure cooking of sweet potatoes increased the moisture content $(77.18 \pm 3.8$ and $75.44 \pm 1.2 \%$ respectively) while microwaving and grilled decreased the moisture content (74.18 \pm 2.2 and $73.03 \pm 1.1 \%$ respectively). These results were in accordance with those Cross et al., (2009), who described that microwave cooking caused in rise moisture loss. The increase of the moisture content after cooking with the boiling process is referred to as an increase in water absorption during boiling.

Protein percentage increased in microwave cooked sweet potato than raw sweet potato $(2.68 \pm 0.3$ and $2.59 \pm 0.2$ respectively). These results agreed with Abong et al., (2009) and Adepoju and Adejumo, (2015) who reported that protein content increases in the microwave cooked samples compared with the raw sweet potato. The increase in the percent might be because of the reduction in the moisture content by microwaved potato Bembem and Sadana (2013).

, Generally the processes of sweet potato caused a remarkable decrease in total lipid from $0.91 \pm 0.1 \%$ (raw sweet potato) to $0.34 \pm 0.0$ $\%$ (boiled sweet potato) the results; also indicated that the shorter cooking time (Microwaved) had a lower fat loss. These obtained 


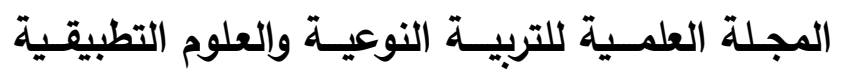

The Scientific Journal of Specific Education and Applied Sciences

results were agreed with those obtained by Mondy and Mueller (1977) who's considered the result of the cooking process on the lipid content of potatoes and exposed that the crude lipid content of potatoes was dropped by all ways of cooking, and their data were agreed with those obtained by Abong et al., (2009), who described that total lipid was reduced on boiling when determining the nutrient contents of raw and processed foods of Kenyan potato cultivars and their investigation agreed with the results were obtained by Bembem and Sadana (2013).

Table (4) showed that the fiber content of cooked potato in the microwave was highest than other treatments. Whereas, cooking of sweet potato in boiling water caused a decrease of fiber content from $0.70 \pm 0.1$ (raw sweet potato) to $0.61 \pm 0.8$ (of boiled sweet potato) $\mathrm{mg} / 100 \mathrm{~g}$. The boiling of sweet potato Table (4) caused a remarkable decrease of the carbohydrate content from $20.83 \pm 2.8 \%$ (of raw sweet potato) to $20.08 \pm 3.0 \%$ (of boiled sweet potato). This could be resulted the thermal degradation and extraction of carbohydrates in boiling water. These results agreed with those stated by Gouado et al., (2011), who showed that there were decreased in the carbohydrate content of sweet potato after boiling and frying, and they assumed that these sufferers might be a result of dispersal of free sugar from food to oil/water during frying or boiling.

Results in Table (4) indicated the result of different processing systems on the mineral composition of sweet potato samples, boiling of sweet potato caused a decrease of mineral contents especially contents of both $\mathrm{Ca}$ and $\mathrm{K}$, while there was an increase of $\mathrm{P}$ contents at the microwaved sample and of Fe and $\mathrm{Mg}$ at the grilled sample. These data agree with Abong et al., (2009), who showed that boiling and storage in a frozen form significantly $(\mathrm{P} \leq 0.05)$ losses total ash, carbohydrates, and mineral content; as well as iron, manganese, zinc, potassium, calcium, and magnesium contents when determining the nutrient contents of raw and processed products of Kenyan potato. 


\section{المجلة العلمـية للتربيـة النوعيـة والعلوم التطبيقية}

The Scientific Journal of Specific Education and Applied Sciences

Table (4): Effect of cooking methods on the chemical composition and minerals of range sweet potato samples.

\begin{tabular}{|c|c|c|c|c|c|c|c|c|c|c|c|c|}
\hline \multirow{2}{*}{$\begin{array}{l}\text { Cooking } \\
\text { method }\end{array}$} & \multirow{2}{*}{$\begin{array}{l}\text { Moisture } \\
(\%)\end{array}$} & \multirow[t]{2}{*}{ Fat $(\%)$} & \multirow{2}{*}{$\begin{array}{c}\text { Curd } \\
\text { Protein } \\
(\%)\end{array}$} & \multirow{2}{*}{$\begin{array}{c}\text { Curd } \\
\text { Fiber } \\
(\%)\end{array}$} & \multirow{2}{*}{$\begin{array}{l}\text { Ash } \\
(\%)\end{array}$} & \multirow{2}{*}{$\begin{array}{c}\text { Carbohydrate } \\
(\%)\end{array}$} & \multirow{2}{*}{$\begin{array}{l}\text { Energy } \\
\text { density }\end{array}$} & \multicolumn{5}{|c|}{ Minerals } \\
\hline & & & & & & & & $\mathbf{C a}$ & $\mathbf{P}$ & $\mathbf{F e}$ & Mg & $\mathbf{K}$ \\
\hline Con. & $74.97 \pm 4.1^{\mathrm{c}}$ & $0.91 \pm 0.1^{\mathrm{a}}$ & $2.59 \pm 0.2^{\mathrm{a}}$ & $0.70 \pm 0.1^{\mathrm{b}}$ & $2.17 \pm 0.1^{b}$ & $20.83 \pm 2.8^{\mathrm{b}}$ & $101.87 \pm 11.1^{\mathrm{a}}$ & 0.88 & 0.16 & 0.57 & 0.15 & 0.92 \\
\hline $\begin{array}{c}\text { Traditional hot } \\
\text { water boiling }\end{array}$ & $77.18 \pm 3.8^{\mathrm{a}}$ & $0.34 \pm 0.0^{\mathrm{d}}$ & $1.79 \pm 0.9^{b}$ & $0.61 \pm 0.8^{c}$ & $2.31 \pm 0.4^{\mathrm{a}}$ & $20.08 \pm 3.0^{\mathrm{b}}$ & $90.54 \pm 5.4^{\mathrm{c}}$ & 0.55 & 0.16 & 0.33 & 0.10 & 0.81 \\
\hline Microwave & $74.18 \pm 2.2^{c}$ & $0.71 \pm 0.3^{b}$ & $2.68 \pm 0.3^{\mathrm{a}}$ & $0.86 \pm 0.1^{\mathrm{a}}$ & $2.24 \pm 0.3^{\mathrm{a}}$ & $21.57 \pm 4.0^{\mathrm{b}}$ & $103.39 \pm 17.1^{\mathrm{a}}$ & 0.57 & 0.18 & 0.28 & 0.15 & 1.01 \\
\hline $\begin{array}{l}\text { Under pressure } \\
\text { cooking }\end{array}$ & $75.44 \pm 1.2^{\mathrm{b}}$ & $0.62 \pm 0.1^{\mathrm{c}}$ & $2.49 \pm 0.7^{\mathrm{a}}$ & $0.68 \pm 0.0^{\mathrm{b}}$ & $2.20 \pm 0.7^{b}$ & $20.77 \pm 1.1^{b}$ & $98.62 \pm 9.7^{b}$ & 0.76 & 0.17 & 0.57 & 0.10 & 0.76 \\
\hline Grilling & $73.03 \pm 1.1^{\mathrm{d}}$ & $0.63 \pm 0.2^{\mathrm{c}}$ & $2.60 \pm 0.1^{\mathrm{a}}$ & $0.72 \pm 0.3^{b}$ & $2.06 \pm 0.0^{c}$ & $23.02 \pm 2.1^{\mathrm{a}}$ & $108.15 \pm 5.5^{\mathrm{a}}$ & 0.80 & 0.16 & 0.63 & 0.17 & 0.72 \\
\hline
\end{tabular}

*Mean values followed by different letters in the same column are significantly different at $\mathrm{P} \leq 0.05$. *Carbohydrate was calculated by difference. 


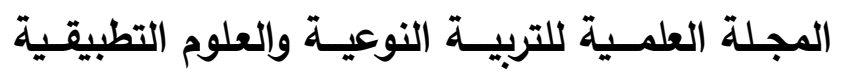

The Scientific Journal of Specific Education and Applied Sciences

\section{Different orange sweet potato jams color parameter}

The chemical composition is illustrated in Table (5) the results showed the increase in protein and carbohydrate contents of the substitution of under pressure cooked orange sweet potato with mixture of pumpkin and carrot comparative with the substitution of under pressure cooked orange sweet potato with pumpkin that was decreased in moisture, protein and carbohydrate content. That increase and decrease rate resulted because of method and recipe used. The crude fiber content increasing in all samples comparative with control sample. These result agree with Takahata et al., (1992) who indicated that the obliteration of the cells, due to easy removal of water from the hot surfaces of treatments the because of these differences samples. Although, adding of pumpkin and carrot there was not affecting the energy density content where decreased in all samples compare with control sample. PH showed that the no difference in levels. With the increase in proportion of water in fruit, there was an increase in $\mathrm{pH}$. The results agree with other researchers that reported that the different sweet potato varieties, the ash and crude fiber contents were reported to be in the ranges of $1.76-4.09 \%$ and $1.43-4.40 \%$, respectively (Shao and Huang 2008). In the same Table showed that the difference in lightness was significant, whereas the highest value of lightness was observed in the control. It also showed that when the vegetable replacement was increased; the lightness was decreased. On the other hand, there were significant differences in redness and yellowness between the control and different treatment. It was shown that when yellow was increased the antioxidant was increased. 


\section{المجلة العلمـية للتربيـة النوعيـة والعلوم التطبيقـية}

The Scientific Journal of Specific Education and Applied Sciences

Table (5): Effect of various substitution ratios with pumpkin and carrot on chemical composition, $\mathrm{pH}$, and color properties of under pressure cooked orange sweet potato jams.

\begin{tabular}{|c|c|c|c|c|c|c|c|c|c|c|c|}
\hline \multirow[t]{2}{*}{ Jam type } & \multirow{2}{*}{$\begin{array}{c}\text { Moisture } \\
(\%)\end{array}$} & \multirow{2}{*}{$\begin{array}{l}\text { Fat } \\
(\%)\end{array}$} & \multirow{2}{*}{$\begin{array}{c}\text { Curd Protein } \\
(\%)\end{array}$} & \multirow{2}{*}{$\begin{array}{c}\text { Curd Fiber } \\
(\%)\end{array}$} & \multirow{2}{*}{$\begin{array}{l}\text { Ash } \\
(\%)\end{array}$} & \multirow{2}{*}{$\begin{array}{c}\text { Carbohydra } \\
\text { tes }(\%)\end{array}$} & \multirow{2}{*}{$\begin{array}{l}\text { Energy } \\
\text { density }\end{array}$} & \multirow[t]{2}{*}{ pH } & \multicolumn{3}{|c|}{ Color parameters } \\
\hline & & & & & & & & & $L^{*}$ & $a^{*}$ & $b^{*}$ \\
\hline Con. & $33.00 \pm 0.1^{\mathrm{a}}$ & $0.55 \pm 0.0^{\mathrm{b}}$ & $1.59 \pm 0.1^{\mathrm{c}}$ & $1.30 \pm 0.1^{\mathrm{c}}$ & $2.75 \pm 0.3^{\mathrm{b}}$ & $62.11 \pm 4.5^{\mathrm{a}}$ & $265.55 \pm 8.4^{\mathrm{a}}$ & 3.67 & $34.51 \pm 3.5^{\mathrm{a}}$ & $3.81 \pm 0.9^{\mathrm{ds}}$ & $13.6 \pm 1.1^{\mathrm{c}}$ \\
\hline T1 & $32.59 \pm 0.1^{\mathrm{a}}$ & $0.65 \pm 0.1^{\mathrm{a}}$ & $1.48 \pm 0.0^{c}$ & $3.00 \pm 0.2^{\mathrm{a}}$ & $2.39 \pm 0.0^{\mathrm{b}}$ & $62.89 \pm 3.3^{\mathrm{a}}$ & $260.89 \pm 6.9^{b}$ & 3.60 & $30.88 \pm 4.0^{\mathrm{b}}$ & $4.56 \pm 0.1^{\mathrm{c}}$ & $17.05 \pm 0.7^{b}$ \\
\hline T2 & $33.21 \pm 0.6^{\mathrm{a}}$ & $0.52 \pm 0.3^{\mathrm{b}}$ & $1.89 \pm 0.0^{\mathrm{b}}$ & $2.01 \pm 0.9^{\mathrm{b}}$ & $3.11 \pm 0.5^{\mathrm{a}}$ & $61.27 \pm 3.2^{\mathrm{a}}$ & $261.72 \pm 4.2^{\mathrm{b}}$ & 3.61 & $29.03 \pm 1.2^{\mathrm{b}}$ & $13.45 \pm 0.3^{\mathrm{a}}$ & $18.41 \pm 1.3^{\mathrm{a}}$ \\
\hline T3 & $32.51 \pm 0.9^{\mathrm{a}}$ & $0.49 \pm 0.0^{\mathrm{c}}$ & $2.01 \pm 0.1^{\mathrm{a}}$ & $2.33 \pm 0.6^{\mathrm{b}}$ & $2.91 \pm 0.1^{\mathrm{a}}$ & $62.08 \pm 5.1^{\mathrm{a}}$ & $263.09 \pm 11.9^{\mathrm{a}}$ & 3.70 & $28.42 \pm 2.7^{\mathrm{c}}$ & $11.01 \pm 0.6^{\mathrm{b}}$ & $19.08 \pm 2.0^{\mathrm{a}}$ \\
\hline
\end{tabular}

*Mean values followed by different letters in the same column are significantly different at $\mathrm{P} \leq 0.05$. Control: under pressure cooked

orange sweet potato; T1: substitution of under pressure cooked orange sweet potato with pumpkin; T2: substitution of under pressure cooked orange

sweet potato with carrot; T3: substitution of under pressure cooked orange sweet potato with mixture of pumpkin and carrot. 


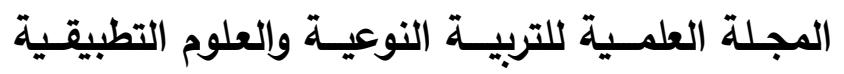

The Scientific Journal of Specific Education and Applied Sciences

\section{Total phenolic and flavonoid contents and antioxidant activity \\ Cooked orange sweet potato}

The outcomes in Table (6) demonstrated that the under pressure cooking sample had the most elevated estimations of total flavonoid component (TFC) and total phenolic component (TPC) $(0.66 \pm 0.0$ and $0.77 \pm 0.1 \mathrm{~g} / \mathrm{g}$ dried extract) followed by cooking grilled sample, cooking boiled sample and cooking microwave sample $(0.62 \pm 0.0,0.55 \pm 0.1$ and $0.51 \pm 0.1 \mathrm{~g} / \mathrm{g}$ dried extrac) for TPC, respectively and $(0.75 \pm 0.1,0.71 \pm 0.0$ and $0.63 \pm 0.1 \mathrm{~g} / \mathrm{g}$ dried extract) for TFC, respectively these outcomes were contrasted and raw potato $(0.78 \pm 0.1$ and $0.83 \pm 0.0 \mathrm{~g} / \mathrm{g} \mathrm{D}$.W $)$ for TPC and TFC, respectively.Total flavonoids and phenolic content were decidedly related with antioxidant activity including $\mathrm{DPPH}+$ scavenging activity and ferric dropping power which was likewise affirmed by Huang et al., (2006) and Teow et al., (2007). The results indicated that the cooking method decreased total polyphenol contents and this agrees with Laib and Barkat (2018) who reported that the three modes of cooking of sweet potato (in water, steam, and microwave) caused a low in the total polyphenol contents, antioxidant and anticholinesterase activities. This lessening may be because of the thermal destruction of these compounds as revealed by Zhao et al., 2017 and the solubilization of convinced phenolic compounds in cooking water as reported by Laib and Barkat (2018).

The lessening in polyphenol content during microwaving may be due to the breakdown of weak hydrogen bonds by dipolar rotation of molecules where was decided by Yeoh et al., 2008. This treatment accelerates the breakdown of the cells by increase in temperature and the internal pressure in the ramparts of plant cells, which can lead to thermal destruction of polyphenols as showed by Inoue, et al., 2010 and Jawad and Langrish, 2012.

In the same Table (6) the outcomes demonstrated that thermal processing (microwaving, boiling, cooking pressure and grilled) of the sweet potato caused in a significant decrease of antioxidant activity, cooking pressure boiled sample had the highest antioxidant activity compared with grilled sample, cooking boiled sample and cooking microwaved sample, which had antioxidant activities as 


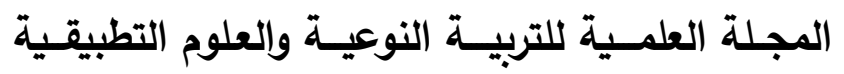

The Scientific Journal of Specific Education and Applied Sciences

followed $61.62 \pm 0.3,59.73 \pm 0.4$ and $55.54 \pm 0.3 \%$, respectively where raw sweet potato had $68.22 \pm 0.5$.

In additional that, the lowest power activities values of the extracts from different processing methods of sweet potatoes were exhibited in Table (6), where the highest antioxidant capacity was recorded $(11.08 \pm 0.2 \mu \mathrm{g} / \mathrm{ml})$ cooking pressure boiled process followed by cooking grilled and cooking boiled $(8.74 \pm 0.1$ and $8.12 \pm$ $0.1 \mu \mathrm{g} / \mathrm{ml}$ ), respectively but the decreased FRAP level was exposed in cooking microwaved $7.69 \pm 0.2 \mu \mathrm{g} / \mathrm{ml}$. It may be realized clearly that the FRAP of all sweet potato species descended after thermal treatments compared with raw potato $11.71 \pm 0.8 \mu \mathrm{g} / \mathrm{ml}$.

After warm treatment, antioxidant capacities for all different cooking methods of sweet potatoes descended, and there was a similar propensity of the outcomes in DPPH and FRAP, in addition to the FRAP esteems likewise demonstrated a comparable pattern to the DPPH trends for different cooking methods of sweet potatoes. These results were in agreement with those obtained by Padda and Picha (2008), who described that thermal processing (microwaving, boiling, and baking) of the sweetpotato skin showed in a significant loss of phenolics and antioxidant activity, but no significant loss was detected caused heat processing of cortex and pith tissue.

Boiling of the plugged roots from the central share with $5 \mathrm{~cm}$ long for $10 \mathrm{~min}$, had a smaller effect on total phenolic content, using by Folin-Ciocalteu and on antioxidative activity by DPPH as defined by Jung et al., 2011. and not agree with those obtained by Ateea et al., 2012 whom reported that thermal processing significantly $(\mathrm{P} \leq$ $0.05)$ bigger the total phenolic content, as healthy individual phenolic acids and antioxidant capacity of all the cultivars under study. The decrease in antioxidant activity may be caused the discount of polyphenols by the many systems of cooking. Normally, the most of literature studies that there is a relationship between the content of phenolic compounds and antioxidant properties as stated by Zhao et al., 2006. 


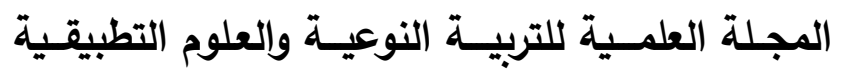

The Scientific Journal of Specific Education and Applied Sciences

Table (6): Total phenolic compounds, total flavonoids and antioxidant activities of processed sweet potato.

\begin{tabular}{|c|c|c|c|c|}
\hline \multirow[b]{2}{*}{$\begin{array}{l}\text { Cooking } \\
\text { method }\end{array}$} & \multirow{2}{*}{$\begin{array}{c}\text { TPC } \\
\text { (g/g dried } \\
\text { extract) }\end{array}$} & \multirow{2}{*}{$\begin{array}{c}\text { TFC } \\
\text { (g/g dried extract) }\end{array}$} & \multicolumn{2}{|c|}{ AOA } \\
\hline & & & DPPH \% & $\begin{array}{c}\text { Reducing power } \\
\text { activity }(\mu \mathrm{g} / \mathrm{ml})\end{array}$ \\
\hline & $0.78 \pm 0.1^{\mathrm{a}}$ & $0.83 \pm 0.0^{\mathrm{a}}$ & $68.22 \pm 0.5^{\mathrm{a}}$ & $11.71 \pm 0.8^{a}$ \\
\hline $\begin{array}{l}\text { Traditional hot } \\
\text { water boiling }\end{array}$ & $0.55 \pm 0.1^{\mathrm{c}}$ & $0.71 \pm 0.0^{\mathrm{b}}$ & $59.73 \pm 0.4^{b}$ & $8.12 \pm 0.1^{\mathrm{b}}$ \\
\hline Microwave & $0.51 \pm 0.1^{\mathrm{c}}$ & $0.63 \pm 0.1^{\mathrm{c}}$ & $55.54 \pm 0.3^{b}$ & $7.69 \pm 0.2^{\mathrm{c}}$ \\
\hline $\begin{array}{l}\text { Under pressure } \\
\text { cooking }\end{array}$ & $0.66 \pm 0.0^{\mathrm{b}}$ & $0.77 \pm 0.1^{\mathrm{a}}$ & $67.25 \pm 0.3^{\mathrm{a}}$ & $11.08 \pm 0.2^{\mathrm{a}}$ \\
\hline Grilling & $0.62 \pm 0.0^{\mathrm{b}}$ & $0.75 \pm 0.1^{\mathrm{b}}$ & $61.62 \pm 0.3^{\mathrm{b}}$ & $8.74 \pm 0.1^{\mathrm{b}}$ \\
\hline
\end{tabular}

Mean values followed by different letters in the same column are significantly different at $\mathrm{P} \leq 0.05$.

\section{Different orange sweet potato jams}

Total flavonoids and phenolic contents are offered in Table (7). The data presented that total flavonoids values between $0.42 \pm$ 0.0 and $0.72 \pm 0.0 \mathrm{~g} / \mathrm{g}$ dried extract and total phenolic content ranged from $0.57 \pm 0.0$ to $0.77 \pm 0.0 \mathrm{~g} / \mathrm{g}$ dried extract it was observed that $\mathrm{T}_{3}$ (Potato, Carrot, and Pumpkin) had the highest values of flavonoids and phenolic contents compared to control, which had the lowest values $(0.42 \pm 0.0$ and $0.57 \pm 0.0$ respectively).

From results in the same Table presented that $\mathrm{T}_{3}$ had the highest values of antioxidant capacity $(65.41 \pm 0.4 \%)$ and $(7.22 \pm$ $0.1 \mu \mathrm{g} / \mathrm{ml})$ followed by $\mathrm{T}_{2}, \mathrm{~T}_{1}$ and control $(53.52 \pm 0.4 \%, 52.46 \pm 0.3$ $\%$, and $43.87 \pm 0.5 \%$ inhibition) against DPPH and (6.16 $\pm 0.2,6.14 \pm$ 0.1 and $4.36 \pm 0.1 \mu \mathrm{g} / \mathrm{ml}$ ) against ferric reducing power this difference is projected due to differences in ingredients and phenolic kinds according to process. It can be noticed that supplements of prepared jam with carrot, pumpkin or both improved the nutritional quality of jam. 


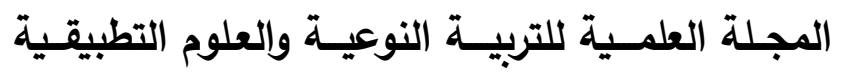

The Scientific Journal of Specific Education and Applied Sciences

Table (7): Total phenolic contents, Total flavonoids and antioxidant activities of sweet potatoes jam

\begin{tabular}{lcccc}
\hline $\begin{array}{l}\text { Jam } \\
\text { types }\end{array}$ & $\begin{array}{c}\text { TPC } \\
\text { (g/g dried } \\
\text { extract) }\end{array}$ & $\begin{array}{c}\text { TFC } \\
(\text { g/g dried } \\
\text { extract) }\end{array}$ & DPPH \% & $\begin{array}{c}\text { AOA } \\
\text { Reducing power } \\
\text { activity }(\boldsymbol{\mu g} / \mathbf{m l})\end{array}$ \\
\hline Con. & $0.57 \pm 0.0^{\mathrm{c}}$ & $0.42 \pm 0.0^{\mathrm{c}}$ & $43.87 \pm 0.5^{\mathrm{c}}$ & $4.36 \pm 0.1^{\mathrm{c}}$ \\
$\mathbf{T}_{\mathbf{1}}$ & $0.71 \pm 0.1^{\mathrm{a}}$ & $0.69 \pm 0.0^{\mathrm{a}}$ & $52.46 \pm 0.3^{\mathrm{b}}$ & $6.14 \pm 0.1^{\mathrm{b}}$ \\
$\mathbf{T}_{\mathbf{2}}$ & $0.66 \pm 0.0^{\mathrm{b}}$ & $0.54 \pm 0.1^{\mathrm{b}}$ & $53.52 \pm 0.4^{\mathrm{b}}$ & $6.16 \pm 0.2^{\mathrm{b}}$ \\
$\mathbf{T}_{\mathbf{3}}$ & $0.77 \pm 0.0^{\mathrm{a}}$ & $0.72 \pm 0.0^{\mathrm{a}}$ & $65.41 \pm 0.4^{\mathrm{a}}$ & $7.22 \pm 0.1^{\mathrm{a}}$ \\
\hline Mean values followed by different letters in the same column are significantly \\
different at $\mathrm{P} \leq 0.05$.
\end{tabular}

\section{Conclusion}

Evaluation of cooking diversity on bio-nutrients of sweet potato showed that all constituents were affected by cooking methods. The content values of nutrients were correlated with the cooking methods. Also fortification of sweet potato jam with carrot, pumpkin or both improved nutritional quality of diet.

\section{References}

Abong, G. O., Michael, W. O., Edward, G. K., Jackson, N. K. and Francis, M. M. (2009): Nutrient contents of raw and processed products from Kenyan potato cultivars .J. Appl. Biosci. 16: 877 - 886 .

Abubakar, H. N., Olayiwola, I. O., Sanni, S. A. and Idowu M. A. (2010): The chemical composition of sweet potato (Ipomeabatatas Lam) dishes as consumed in Kwara state, Nigeria.Int. Food Res. J. 17: 411-416.

Adepoju, A. L. and dejumo B. A.A. (2015): Some proximate properties of sweet potato (ipomoeabatatas 1) as influenced by cooking methods.Int. J. of Sci. \&technolo. Res., 4, 146148.

AOAC (1990): Association of Official Analytical Chemists.Official Methods of Analysis $15^{\text {th }} \mathrm{ed}$. AOAC, Washington DC. 


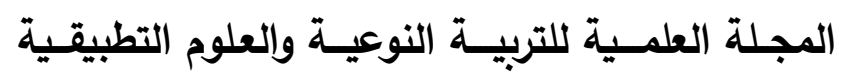

The Scientific Journal of Specific Education and Applied Sciences

AOAC (2005): Official Methods of Analysis of Association of official Analytical chemists. $18^{\text {th }}$ ed. Gaithersburg, Maryland, USA, AOAC International.

Arscot, S. A. and Tanumihardio, S. A. (2010): Carrots of many colors provide basic nutrition and bioavailable phytochemicals acting as a functional food. Comprehensive Reviews in Food Science and Food Safety, 9(2): 223-239.

Ateea A. B., Omayma, E. S., Mohammed, M. Y. and Ahmed, M. A. E. (2012): Effect of Home-Cooking Methods on Phenolic Composition and Antioxidant Activity of Sweetpotato (Ipomoea batatas (L.) Lam.) Cultivars Grown in Egypt Food and Nutrition Sciences, 3, 490-499.

Bao, B. and Chang, K. C (1994): Carrot pulp chemical composition, colour and waterholdingcapacity as affected by blanching. J Food Sci 59: 1159-1161.

Bembem, K. and Sadana, B. (2013): Effect of cooking methods on the nutritional composition and antioxidant activity of potato tubers.Int. J. of Food and Nutri.Sci.2, e-ISSN 2320 -7876.

Benjamin (2007): Rheology and Chemistry of Dough. In: Pomeranz Y (ed) Wheat Chemistry and Technology. (3rd edn), American Association of Cereal Chemists, Minnesota.

Cross, G. A., Fung D. Y. C. and Decareau, R. V. (2009): The effect of microwaves on nutrient value of foods.CRC Critical Rev Food Nutri.

Desrosier, N. W. and Desrosier, J. N. (1977): The Technology of food preservation. The Avi publishing Com., Second Edition, West port, USA.p.45-49.

Devi, N., Rashmi, P. and Sagarika, N. (2018): A review on health benefits and nutritional composition of pumpkin seeds. International Journal of Chemical Studies; 6 (3): 1154-1157.

Gouado, I., Demasse, M. A., Etame, L. G., Meyimgo, O. R., Solange, E. A. R. and Fokou, E. (2011): Impact of three cooking methods (steaming, roasting on charcoal and frying) on the $\beta$-carotene and vitamin c contents of plantain and sweet potato. Am. J. of Food Technol. 6: 994-1001.

Guzman, G. M., Morais, F., Ramos, M. and Amigo, L. (1999): Influence of skimmed milk concentrate replacement by dry dairy products in a low fat set-type youghurt mode system. J. Food Sci., and Agric., 79: 1117-1112. 


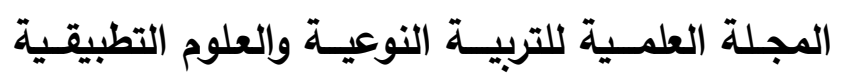

The Scientific Journal of Specific Education and Applied Sciences

Huang, Y. C., Chang, Y. H. and Shao, Y. Y. (2006): Effects of Genotype and Treatment on the Antioxidant Activity of Sweet Potato in Taiwan," Food Chemistry, 98. 3. 529-538.

Imen, L. and Malika, B. (2018): Optimization of Conditions for Extractionof Polyphenols and the Determination of the Impact of Cooking on Total Polyphenolic, Antioxidant, and nticholinesterase Activities of Potato. J. Foods 2018, 7, 36

Ingabire, M. R. and Hilda, V. (2011): Comparison of the Nutrient composition of four sweet potato varieties cultivated in Rwanda. Am. J. Food. Nutr, 1(1): 34-38

Inoue, T., Tsubaki, S., Ogawa, B., Onishi, K. and Azuma, J. I. (2010). Isolation of hesperidin from peels of thinned Citrus unshiu fruits by microwave-assisted extraction. Food Chem., $123,542-547$.

Insel, P., Turner R. E. and Ross D. (2002): Nutrition.Jones and Bartlett pub., Inc. USA.

Jackson, M. L. (1973): Soil Chemical Analysis.Prentice Hall of India Private Limited, New Delhi.

Jawad, A. and Langrish, T. A. G. (2012): Optimisation of total phenolic acids extraction from mandarin peels using microwave energy: The importance of the Maillard reaction. J. Food Eng., 109, 162-174.

Jung, J., Lee, S., Kozukue, N., Levin, C. and Friedman, M. (2011): "Distribution of Phenolic Compounds and Antioxidative Activities in Parts of Sweet Potato (Ipomoea batata L.) Plants and in Home Processed Roots," Journal of Food Composition and Analysis, 24, (1), 29-37.

Krinsky, N. I., Johmson, E. J. (2005): Carotenoid actions and their relation tohealthand diseases. Mol Aspect Med 26: 459-516.

Laib, I. and Barkat, M. (2016): Impact of cooking and conservation for twelve days on total polyphenols content, antioxidant and anticholinesterase activities of red onion. Afr. J. Pharm. Pharmacol., 10, 270-277.

Laib, I. and Barkat, M. (2018): Optimization of Conditions for Extraction of Polyphenols and the Determination of the Impact of Cooking on Total Polyphenolic, Antioxidant, and nticholinesterase Activities of Potato. J. Foods 2018, 7, 36.

Leite, P. B., Bispo, E. D. S. and Santana, L. R. R. D. (2013). Sensory profiles of chocolates produced from cocoa 


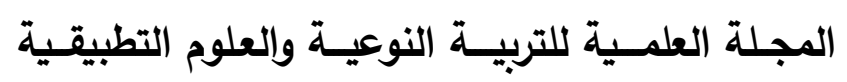

The Scientific Journal of Specific Education and Applied Sciences

cultivars resistant to Moniliophtora perniciosa. Revista Brasileria de Fruticultura, 35:594-602.

Milind, p. and Monika (2015): Sweet potato as a super-food. Int. J. Res. Ayurveda Pharma.6(4) 557-562.

Mondy N. I. and Muller T. O. (1977): The effect of cooking methods on the lipid composition of potatoes. Amer. Potato J. 54:203-210.

Mounir, S., T_ellez-P_erez, C., Sunooj, K. V. and Allaf, K. (2019). Texture and Color Characteristics of Swell-Dried Ready-toEat Zaghloul Date Snacks: Effect of Operative Parameters of Instant Controlled Pressure Drop Process. Journal of Texture Studies, 51, 276-214.

Mukesh, Y. Shalini, J., Radha, T., Prasad, G. B. K. S. and Hariom, Y. (2010). Medicinal and biological potential of pumpkin: an updated review Nutrition Research Reviews, 23, 184-190.

Nalinde, A., Ashish, M., Nikhil, B., Swapnil, B. and Sachin, J. (2018): Development and quality evaluation of sweet potato jam blended with carrot. International Journal of science and Research 7, 11, 109-112.

Oke, M. O. and Workneh, T. S. (2013): A review on sweet potato postharvest processing and preservation technology.Afri.J.of Agric. Res. 8(40), 4990-5003.

Padda, M. S. and Picha, D. H. (2008): "Phenolic Composition and Antioxidant Capacity of Different Heat-Processed Forms of Sweetpotato cv. 'Beauregard'," International Journal of Food Science \& Technology43, (8), 1404-1409.

Padmaja, G. (2009): "Uses and Nutritional Data of Sweetpotato," In: G. Loebenstein and G. Thottappilly, Eds., the Sweetpotato, Springer, Dordrecht, pp. 189-234.

Quettier-Deleu, C., Gressier, B., Vasseur, J., Dine, T, Brunet, C., Luyckx, M., Cazin, M., Cazin, J.,Bailleul, F. and Trotin, F.(2000): Phenolic compounds and antioxidant activities of buckwheat (Fagopyrum esculentum Moench) hulls and flour. J Ethnopharmacol 72(1-2): 35-42.

Rababah, T. M., Hettiarachchy, N. S and Horax, R. (2004): Total phenolics and antioxidant activity of fenugreek, green tea, 


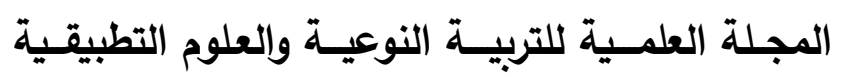

The Scientific Journal of Specific Education and Applied Sciences

black tea, grape seed, ginger, rosemary, Gotukola, and ginkgo extracts, vitamin E, and tert-butyl hydroquinone. J Agric Food Chem 52:5183-5186.

Rose, I. and Vasanthakaalam, H. (2011): Comparison of the Nutrient composition of four sweet potato varieties cultivated in Rwanda, Biology American Journal of Food and Nutrition Sathe, S. K and Salunkhe, D. K. (1999): Functional properties of the great northern bean protein: emulsion, foaming, viscosity and gelation properties. J. Food Sci 46: 71-76.

Shao, Y. Y. and Huang, Y. C. (2008): Effect of steaming and kneading with presteaming treatments on the physicochemical properties of various genotypes of sweet potato (Ipomoea batatas L.). J Food Process Eng. 31:739753.

Sharma K. D., Karki S., Thakur N. S. and Attri S. (2012): Chemical composition, functional properties and processing of carrot - a review.J. Food Sci. Technol., 49(1): 22-32. DOI: 10.1007/s13197-011-0310-7.

Siems, S., Wiswedel, I. Salerno, C., Crifo, C., Augustin, L. S., Langhans, C. D. and Sommerberg, O. (2005): $\beta$-carotene breakdown products may impair mitochondrial functions Potential side effects of high dose $\beta$-carotene supplementation. J. Nutr. Biochem., 16: 385-397.

Spss Inc. (2007): Spss for windows.Release 16.0 SpssInc.Chicago, IL.USA.

Srivastava, S., Genitha, T. R. and Yadav, V. (2012): Preparation and quality evaluation of flour and biscuit from sweet potato.J Food Process Technol., 3:12.

Takahata, Y., Noda, T. and Nagata, T. (1992): Varietal diversity of sugar composition in storage root of sweet potato. Jpn J Breed 42:515-521.

Teow, C. C., Truong, V. D., McFeeters, R. F., Thompson, R. L., Pecota, K. V., Yencho, G. C. (2007): Antioxidant activities, phenolic and $\beta$ - carotene contents of sweet potato genotypes with varying flesh colors. Food Chemistry, 103, 829-838. 


\section{المجلة العلمـية للتربيـة النوعيـة والعلوم التطبيقـية}

The Scientific Journal of Specific Education and Applied Sciences

Tsai, C. Y., Dalby, A. and Jones, R. A. (1975): Lysine and tryptophan increased during germination of maize seed. Cereal Chem., 52-356.

Ullah, N., Ullah, S., Khan, A., Ullah, I. and Badshah, S. (2018): Preparation and Evaluation of Carrot and Apple Blended Jam. J Food Process Technol. 9:4

Vijayakshmi, M. and Kandasamy, R. (2016): Ferric reducing antioxidant power assay in plant extract, Bangladesh J. of Phamacology. 11(3):570.

Wade, P. (1988): Biscuits, cookies and crackers: the principles of craft. 1:1-4.

Woolfe, J. A. (1992): Sweet potato. An Untapped Food Resource, Cambridge University Press, Cambridge, U.K., pp. 118187.

Xu, S. K. C. and Chang, A. (2007): comparative study on phenolic profiles and antioxidant activities of legumes as affected by extraction solvents, J. Food Sci. 72, 159-166.

Yeoh, S., Shi, J., Langrish, T. A. G. (2008): Comparisons between different techniques for water-based extraction of pectin from orange peels. Desalination, 218, 229-237.

Zhao, H., Dong, J., Lu, J., Chen, J., Lin, Y. and Shan, L. (2006): Effects of extraction solvents mixtures on antioxidant activity evaluation and their extraction capacity and selectivity for free phenolic compounds in barley (Hordeumvulgare L.). J. Agric. Food Chem., 54, 7277-7286.

Zhao, Y. Wu, X. Yu, L. and Chen, P. (2017): Retention of polyphenols in blueberries (Vacciniumcorymbosum) after different cooking methods, using UHPLC-DAD-MS based metabolomics. J. Food Compos. Anal., 56, 55-66. 


\section{المجلة العلمـية للتربيـة النوعيـة والعلوم التطبيقـية}

The Scientific Journal of Specific Education and Applied Sciences

\section{التأثيزات الهمتملة لظروف الطهى والاستبدال بالجزد واليقطين علي صفات جودة هربي البطاطا الحلوه البز تقاليئ}

حنان السيد

قسم علوم الأغذية (إقتصاد منزلى ريفى) كلية الزراعة، جامعة الزقازيق، مصر طه فتحى طه قسم الكيمياء الحيوية، كلية الزراعة، جامعة الزقازيق، مصر إيمان طلعت أبو السيد أحمد

قسم علوم الأغذية (إقتصاد منزلى ريفى) كلية الزراعة، جامعة الزقازيق، مصر الملخص العربى

هدفت الدراسة الحالية إلى تحديد طريقة الطهي المناسبة للبطاطا الحلوة وتقييم تأثير نسب الاستبدال المختلفة بالجزر واليقطين على صفات جودة مربى البطاطا الحلوة (الخصائص الحسية ، التركيب الكيميائي ، محتويات الفينول والفلافونويد الكلية ، نشاط مضادات الأكسدة ، و اللون). وتضمنت المعاملات الحرارية الميكروويف ، والثي ، والغليان التقليدي ، والغليان تحت الضغط. أظهرت الملاحظات الأولية أن الغليان تحت الضغط كان أفضل معاملة حرارية للبطاطا الحلوة مع الحفاظ على المستويات القصوى لمحتويات الفينول والفلافونويد الكلية والنشاط المضاد للأكسدة. تم تحضير المربى من البطاطا الحلوة المعاملة تحت الضغط (مجموعة الكنترول) ومن مكملات مختلفة من اليقطين والجزر. وأشارت النتائج إلى وجود انخفاض طفيف بسبب المعاملة الحرارية لمحتويات البوليفينول الكلية

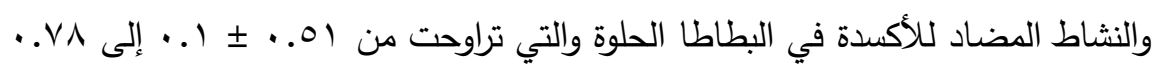
I 1. الغليان بالضغط أقل انخفاض بين طرق المعاملات الأربعة (الميكروويف ، الغليان ، الثي ، الغليان بالضغط). كما أشارت النتائج إلى أن مربى البطاطا المزوج بالجزر والقرع كان بان له أعلى محتوى إجمالي من مادة البوليفينول ونشاط مضاد للأكسدة VV. . . . . . . .

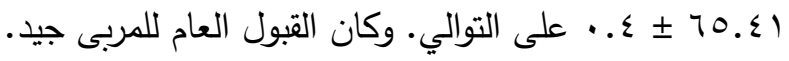
الكلمات المفتاحية: البطاطا الحلوة ، الطبخ ، المحتوى الفينولي الكلي ، الفلافونويد ، النشاط المضاد للأكسدة ، اللون. 